\title{
ANALISIS PENGUKURAN TINGKAT KEMATANGAN SISTEM INFORMASI AKADEMIK MENGGUNAKAN COBIT 5.0 DI POLITEKNIK X
}

\author{
Candra Mecca Sufyana ${ }^{{ }^{*}}$, Edi Suharto ${ }^{2}$ \\ 1,2Program Studi Manajemen Informatika, Politeknik Piksi Ganesha Bandung, Bandung, Indonesia \\ *Email: ecan.mecca@gmail.com
}

\begin{abstract}
Abstrak
The research objective was to evaluate and determine how far the application of information system academic that are running (including management controls and application controls) have been able to provide reliable information and where time and reduce risk to an acceptable level by the Polytechnic also provides recommendations for Polytechnic in order to minimize the risk that existed at themoment. This research describes the IT governance maturity level analysis of the Polytechnic X Academic Information System using COBIT 5.0 framework. This research will find the value of the IT governance maturity level current conditions of STMIK Lombok's Academic Information System management. This maturity level value as a measure of the alignment of the implementation of the Academic Information System to Improve customer orientation and service and Services. Base on the maturity level average calculation results of Implementation the Polytechnic Academic Information System using DSS Domain are at level 3. The results of this study was to determine the academic of information system applications can provide adequate and reliable information and timely, thus simplifying the management to make sound decisions related to academic policy.
\end{abstract}

Keywords: Governance, Maturity level, Academic information systems

\section{PENDAhuluan}

Evaluasi terhadap tata kelola teknologi informasi menggunakan COBIT framework telah banyak diteliti dan hasil rekomendasinya sudah banyak membantu perusahaan memperbaiki tata kelola teknologi informasi menjadi lebih baik. Seperti penelitian dalam bidang perbankan (Etzler, 2007). Dalam tesisnya membahas tentang bagaimana seharusnya teknologi informasi dikelola dan bagaimana COBIT dapat digunakan sebagai pedoman meningkatkan efektivitas dan efesiensi organisasi teknologi informasi untuk mendukung bisnis. Penelitian Marrone et al. (2010) tentang menyelaraskan teknologi informasi dengan bisnis, Simonsson (2008) bagaimana teknologi informasi dapat membantu mengambil keputusan, Weill \& Ross, (2004), Benaroch \& Chernobai (2012), Tai (2010), Goldschmidt et al (2007) bependapat bahwa teknologi informasi yang dikelola dengan baik akan menghasilkan keselarasan antara bisnis dan teknologi informasi. Penelitian dalam bidang yang sama juga telah dilakukan Sasongko (2009), pada penelitian mengemukakan bahwa kinerja pelayanan satu bank dapat dilihat dari kepuasan pelanggan, salah satu didukung dengan kecepatan transfer data dan layanan ATM yang selalu online. Kedua topik di atas dievaluasi dengan menggunakan COBIT 4.1 dan mendapati bahwa bank X. telah mencapai level 3,7 artinya teknologi informasi telah dikelola dengan baik, keamanan sistem jaringan, telah dilakukan dengan baik. Penelitian Heidari et al. (2012) pada bank Refah Iran mendapati bahwa tata kelola teknologi informasi yang baik mampu memberikan pelayan yang baik pula sehingga meningkatkan profit perusahan.

Salah satu bentuk implementasi Teknologi Informasi (TI) pada kampus yaitu Sistem Informasi Akademik (SIA). Teknologi Informasi (TII diperlukan dalam pelaksanaan layanan akademik dapat mendukung kenyamanan, kemudahan, dan kecepatan dalam layanan akademik, sehingga layanan akademik yang berkualitas dapat diberikan kepada mahasiswa. Selain itu, persoalan mengenai pengelolaan data akademik menjadi poin yang sangat penting dan harus diperhatikan dengan baik supaya kegiatan perkuliahan dapat berjalan dengan lancar. Untuk menjamin kualitas pendidikan di Politeknik harus ditunjang oleh sarana dan prasarana yang lengkap seperti gedung, ruangan kelas yang nyaman, peralatan dan perlengkapan kegiatan belajar mengajar, tenaga pengajar yang kompeten sesuai keahlian bidangnya, tenaga administrasi, penguasaan teknologi informasi, dan penyesuaian kurikulum bagi para mahasiswa agar mereka memiliki pemahaman dan keterampilan ilmu.

Upaya yang dilakukan Politeknik $\mathrm{X}$ dalam mendukung pencapain visi misi lembaga untuk meningkatkan orientasi dan pelayanan pelanggan dengan mengimplementasikan aplikasi Sistem Informasi Akademik. Bertujuan untuk merubah pola proses administrasi akademik mahasiswa. Sistem ini mendukung aktivitas akademik mahasiswa untuk pengisian Kartu Rencana studi, Nilai, Pembayaran, 
Kartu. Untuk mendapatkan nilai tingkat kematangan pengelolaan saat ini, harus diadakan tindakan audit pada Sistem Informasi Akademik yang berdasar pada standar kerangka kerja baku yang mencakup pada seluruh tingkatan proses bisnis penyellenggaraan. COBIT (Control Objectives for Information and Related Technology) standar kerangka kerja baku internasional yang digunakan untuk melakukan audit tingkat kematangan tata kelola proses-proses penyelenggaraan dalam pengelolaan Teknologi Informasi (TI). Kerangka kerja COBIT dibangun dari visi misi dan kebijakan institusi maka dapat diadopsi oleh penggunanya dalam peningkatan tata kelola. Hasil analisis dari semua proses akan menunjukkan tingkat kematangan kondisi saat ini terhadap keseimbangan antara tujuan yang akan dicapai dari implemetasi TI terhadap kebijakan yang diimplementasikan oleh pihak penyelenggara.

Audit tata kelola bertujuan untuk mendapatakan nilai tingkat kematangan saat ini dan rekomendasi untuk menaikkan nilai satu tingkat. Nilai dan rekomendasi akan menjadi masukan dan panduan pihak penyelenggara untuk pelaksanaan. Audit dilakukan menggunakan framework COBIT 5.0 dan tidak dibandingkan dengan framework lain pada objek penelitian hanya bagian Sistem Informasi Akademik Politeknik X.

\section{MATERI DAN METODE}

Control Objectives for Information and Related Technology (COBIT) dapat definisikan sebagai alat pengendalian untuk informasi dan teknologi terkait dan merupakan standar terbuka untuk pengendalian terhadap teknologi informasi yang dikembangkan oleh Information System Audit and Control Association (ISACA) melalui lembaga yang dibentuknya yaitu Information and Technology Governance Institute (ITGI) pada tahun 1992. Cobit yang pertama kali diluncurkan pada tahun 1996, mengalami perubahan berupa perhatian lebih kepada dokumen sumber,revisi pada tingkat lebih lanjut serta tujuan pengendalian rinci dan tambahan seperangkat alat implementasi (implementation tool set) pada edisi keduanya yang dipublikasikan pada tahun 1998. Cobit pada edisi ketiga ditandai dengan masuknya penerbit utama baru COBIT yaitu ITGI. COBIT edisi keempat merupakan versi terakhir dari tujuan pengendalian untuk informasi dan teknologi terkait.

Menurut Sarno (2009: 19) . COBIT mendefinisikan tujuan bisnis terkait dengan aktivitas teknologi informasi yang umumnya ada di perusahaan. Pada kerangka kerja COBIT hanya menjelaskan tujuantujuan bisnis yang berkaitan dengan proses teknologi informasi. Demi memudahkan proses kontrol, COBIT mengelompokkan tujuan tersebut ke dalam perspektif kinerja Balanced Scorecard (ITGI, COBIT 4.1, 2007). Perusahaan/organisasi mungkin tidak memiliki semua tujuan bisnis seperti yang dikelompokkan dalam tabel tersebut. Dalam penyusunan tujuan bisnis, perusahaan dapat memilih yang sesuai dengan karakteristik organisasinya masing-masing. Pemilihan tujuan bisnis dapat dilakukan dengan mendefinisikan proses bisnis utama maupun bisnis pendukung organisasi terlebih dahulu.

Tujuan diluncurkan COBIT adalah untuk mengembangkan, melakukan riset dan mempublikasikan suatu standar teknologi informasi yang diterima umum dan selalu up to date untuk digunakan dalam kegiatan bisnis sehari-hari. Dengan bahasa lain, COBIT dapat pula dikatakan sebagai sekumpulan dokumentasi best practices untuk Teknologi Informasi (IT) governance yang dapat membantu auditor, manajemen and pengguna (user) untuk menjembatani gap antara risiko bisnis, kebutuhan kontrol dan permasalahan-permasalahan teknis melalui pengendalian terhadap masing-masing dari 34 proses Teknologi Informasi (IT), meningkatkan tingkatan kemapanan proses dalam Teknologi Informasi (IT) dan memenuhi ekspektasi bisnis dari Teknologi Informasi (IT). COBIT mampu menyediakan bahasa yang umum sehingga dapat dipahami oleh semua pihak. Adopsi yang cepat dari COBIT di seluruh dunia dapat dikaitkan dengan semakin besarnya perhatian yang diberikan terhadap corporate governance dan kebutuhan perusahaan agar mampu berbuat lebih dengan sumber daya yang sedikit meskipun ketika terjadi kondisi ekonomi yang sulit.

Fokus utama COBIT adalah harapan bahwa melalui adopsi COBIT ini perusahaan akan mampu meningkatkan nilai tambah melalui penggunaan Teknologi Informasi (TI) dan mengurangi resiko-resiko inheren yang teridentifikasi didalamnya. Untuk mengetahui keterkaitan antara tujuan bisnis dengan tujuan teknologi informasi, maka perlu dipahami terlebih dahulu keseluruhan tujuan teknologi informasi yang telah didefinisikan dan diklasifikasikan pada kerangka kerja COBIT (ITGI, COBIT 4.1, 2007). Pemetaan tujuan teknologi informasi tersebut dapat dijadikan acuan bagi perusahaan/ organisasi dalam menerjemahkan kebutuhan bisnis akan ketersediaan teknologi informasi. Perlu diketahui bahwa tujuan bisnis yang dipaparkan hanya merupakan tujuan yang terkait atau yang dapat membangkitkan bisnis.

Cobit berorientasi proses, dimana secara praktis Cobit dijadikan suatu standar panduan untuk membantu mengelola suatu organisasi mencapai tujuannya dengan memanfaatkan IT. Cobit memberikan panduan kerangka kerja yang bisa mengendalikan semua kegiatan organisasi secara detail dan jelas sehingga dapat membantu memudahkan pengambilan keputusan di level top dalam organisasi. COBIT 
digunakan secara umum oleh mereka yang memiliki tanggung jawab utama dalam alur proses organisasi, mereka yang organisasinya sangat bergantung pada kualitas, kehandalan dan penguasaan teknologi informasi. Menurut Surendro (2004: 243) karakteristik utama kerangka kerja COBIT adalah pengelompokkan aktivitas teknologi informasi dalam empat domain, yaitu Plan and Organise (PO), Acquire and Implement (AI), Deliver and Support (DS) serta Monitor and Evaluate (ME). Domain PO menyediakan arahan untuk mewujudkan solusi penyampaian (AI) dan penyampaian jasa (DS). solusi penyampaian (AI) menyediakan solusi dan menyalurkannya untuk dapat diubah menjadi jasa. Sementara penyampaian jasa (DS) menerima solusi tersebut dan membuatnya lebih bermanfaat bagi pengguna akhir. Sedangkan ME memonitor seluruh proses untuk kepastian bahwa arahan yang diberikan telah diikuti. Cobit memiliki 4 cakupan domain sebagai berikut :

a. Perencanaan dan Organisasi (Plan and Organize) Domain ini mencakup strategi dan taktik yang menyangkut identifikasi tentang bagaimana TI dapat memberikan kontribusi terbaik dalam pencapaian tujuan bisnis organisasi sehingga terbentuk sebuah organisasi yang baik dengan infrastruktur teknologi yang baik pula.

b. Pengadaan dan Implementasi (Acquire and Implement) Untuk mewujudkan strategi TI, solusi TI perlu diidentifikasi, dibangun atau diperoleh dan kemudian diimplementasikan dan diintegrasikan dalam proses bisnis.

c. Pengantaran dan Dukungan (Deliver and Support) Domain ini berhubungan dengan penyampaian layanan yang diinginkan, yang terdiri dari operasi pada security dan aspek kesinambungan bisnis sampai dengan pengadaan training.

d. Pengawasan dan Evaluasi (Monitor and Evaluate) Semua proses TI perlu dinilai secara teratur dan berkala bagaimana kualitas dan kesesuaiannya dengan kebutuhan kontrol. Keterkaitan domain dalam COBIT disajikan pada Gambar 1 dan Gambar 2.

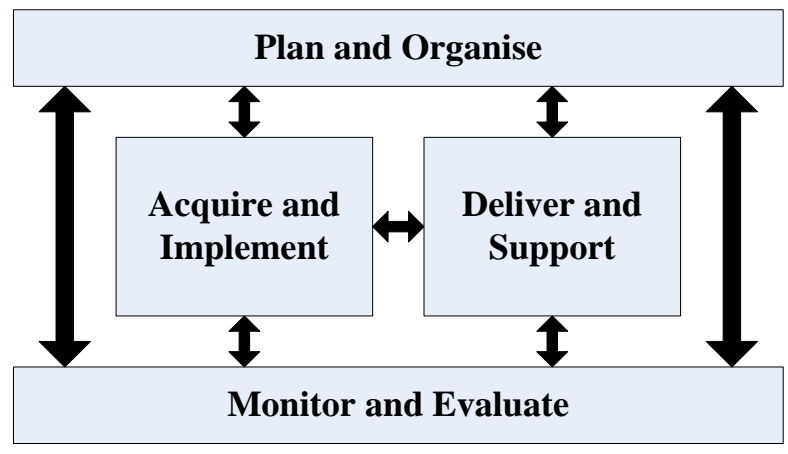

Gambar 1. Keterkaitan Domain dalam COBIT

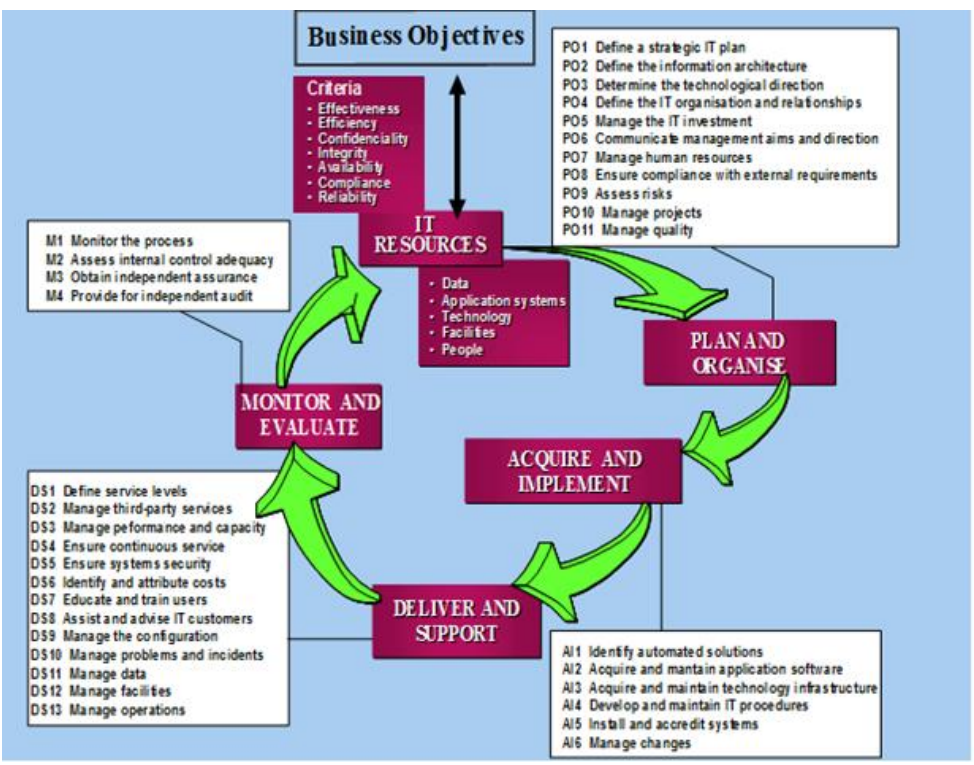

Gambar 2. Kerangka COBIT 
Keempat domain tersebut diatas kemudian dijabarkan menjadi 34 faktor resiko yang harus dievaluasi jika ingin diperoleh suatu kesimpulan mengenai seberapa besar kepedulian manajemen terhadap teknologi informasi, serta bagaimana teknologi informasi dapat memenuhi kebutuhan manajemen akan informasi.

Maturity model adalah suatu metode untuk mengukur level pengembangan manajemen proses, yang berarti adalah mengukur sejauh mana kapabilitas manajemen tersebut. Seberapa bagusnya pengembangan atau kapabilitas manajemen tergantung pada tercapainya tujuan-tujuan COBIT yang. Sebagai contoh adalah ada beberapa proses dan sistem kritikal yang membutuhkan manajemen keamanan yang lebih ketat dibanding proses dan sistem lain yang tidak begitu kritikal. Di sisi lain, derajat dan kepuasan pengendalian yang dibutuhkan untuk diaplikasikan pada suatu proses adalah didorong pada selera resiko Enterprise dan kebutuhan kepatuhan yang diterapkan. Penerapan yang tepat pada tata kelola TI di suatu lingkungan Enterprise, tergantung pada pencapaian tiga aspek maturity (kemampuan, jangkauan dan kontrol). Peningkatan maturity akan mengurangi resiko dan meningkatkan efisiensi, mendorong berkurangnya kesalahan dan meningkatkan kuantitas proses yang dapat diperkirakan kualitasnya dan mendorong efisiensi biaya terkait dengan penggunaan sumber daya TI. Maturity model dapat digunakan untuk memetakan:

a. Status pengelolaan TI perusahaan pada saat itu.

b. Status standart industri dalam bidang TI saat ini (sebagai pembanding)

c. Status standart internasional dalam bidang TI saat ini (sebagai pembanding)

d. Strategi pengelolaan TI perusahaan (ekspetasi perusahaan terhadap posisi pengelolaan TI perusahaan)

Tingkat kemampuan pengelolaan TI pada skala maturity dibagi menjadi 6 level :

a. Level 0 (Non-existent)

Perusahaan tidak mengetahui sama sekali proses teknologi informasi di perusahaannya.

b. Level 1 (Initial Level)

Pada level, organisasi pada umumnya tidak menyediakan lingkungan yang stabil untuk mengembangkan suatu produk baru. Ketika suatu organisasi kelihatannya mengalami kekurangan pengalaman manajemen, keuntungan dari mengintegrasikan pengembangan produk tidak dapat ditentukan dengan perencanaan yang tidak efektif, respon sistem. Proses pengembangan tidak dapat diprediksi dan tidak stabil, karena proses secara teratur berubah atau dimodifikasi selama pengerjaan berjalan beberapa form dari satu proyek ke proyek lain. Kinerja tergantung pada kemampuan individual atau term dan variasi dengan keahlian yang dimilikinya.

c. Level 2 (Repeatable Level)

Pada level, kebijakan untuk mengatur pengembangan suatu proyek dan prosedur dalam mengimplementasikan kebijakan tersebut ditetapkan. Tingkat efektif suatu proses manajemen dalam mengembangankan proyek adalah institutionalized, dengan memungkinkan organisasi untuk mengulangi pengalaman yang berhasil dalam mengembangkan proyek sebelumnya, walaupun terdapat proses tertentu yang tidak sama. Tingkat efektif suatu proses mempunyai karakteristik seperti; practiced, dokumentasi, enforced, trained, measured, dan dapat ditingkatkan. Product requirement dan dokumentasi perancangan selalu dijaga agar dapat mencegah perubahan yang tidak diinginkan.

d. $\quad$ Level 3 (Defined Level)

Pada level ini, proses standar dalam pengembangan suatu produk baru didokumentasikan, proses ini didasari pada proses pengembangan produk yang telah diintegrasikan. Proses-proses ini digunakan untuk membantu manejer, ketua tim dan anggota tim pengembangan sehingga bekerja dengan lebih efektif. Suatu proses yang telah didefenisikan dengan baik mempunyai karakteristik; readiness criteria, inputs, standar dan prosedur dalam mengerjakan suatu proyek, mekanisme verifikasi, output dan kriteria selesainya suatu proyek. Aturan dan tanggung jawab yang didefinisikan jelas dan dimengerti. Karena proses perangkat lunak didefinisikan dengan jelas, maka manajemen mempunyai pengatahuan yang baik mengenai kemajuan proyek tersebut. Biaya, jadwal dan kebutuhan proyek dalam pengawasan dan kualitas produk yang diawasi.

e. Level 4 (Managed Level)

Pada level ini, organisasi membuat suatu matrik untuk suatu produk, proses dan pengukuran hasil. Proyek mempunyai kontrol terhadap produk dan proses untuk mengurangi variasi kinerja proses sehingga terdapat batasan yang dapat diterima. Resiko perpindahan teknologi produk, prores 
manufaktur, dan pasar harus diketahui dan diatur secara hati-hati. Proses pengembangan dapat ditentukan karena proses diukur dan dijalankan dengan limit yang dapat diukur.

f. Level 5 (Optimized Level)

Pada level ini, seluruh organisasi difokuskan pada proses peningkatan secara terus-menerus. Teknologi informasi sudah digunakan terintegrasi untuk otomatisasi proses kerja dalam perusahaan, meningkatkan kualitas, efektifitas, serta kemampuan beradaptasi perusahaan. Tim pengembangan produk menganalisis kesalahan dan defects untuk menentukan penyebab kesalahannya. Proses pengembangan melakukan evaluasi untuk mencegah kesalahan yang telah diketahui dan defects agar tidak terjadi lagi. Urutan tingkat kematangan disajikan pada Gambar 3.

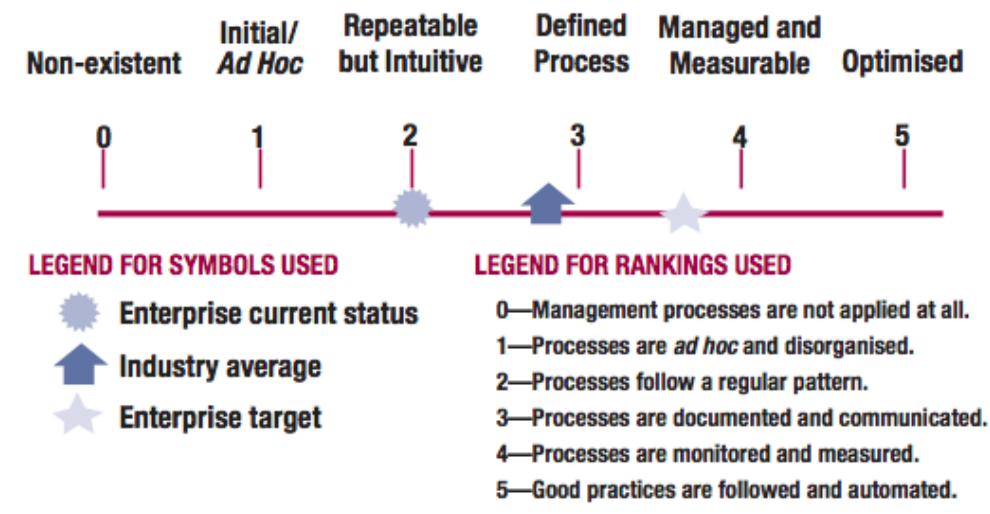

Gambar 3. Urutan Tingkat Kematangan (sumber: ITGI, 2007)

Jika di kelompokan berdasarkan nilai level kematangan maka dapat dirinci. Level Kematangan tata kelola teknologi informasi pada perusahaan disajikan pada Tabel 1.

Tabel 1. Level Kematangan Tata Kelola Teknologi Informasi Pada Perusahaan

\begin{tabular}{ll}
\hline \multicolumn{1}{c}{ Indek Kematangan } & \multicolumn{1}{c}{ Level Kematangan } \\
\hline $0-0.49$ & $0-$ Non-Existent \\
$0.50-1.49$ & 1 -Initial/Ad Hoc \\
$1.50-2.49$ & 2 -Repeatable But Intutitive \\
$3.50-4.49$ & 4 -Managed and Measureabel \\
$4.50-5.00$ & 5 -Optimized \\
\hline
\end{tabular}

(Sumber: ITGI, 2007)

\section{HASIL DAN PEMBAHASAN}

\subsection{Pemetaan Enterprise Goals dengan IT - Related Goals dan Domain DSS}

Pemetaan yang dilakukan pada hubungan sama dengan yang dilakukan pada hubungan Enterprise Goals dengan Tujuan perusahaan. Jika hubungan keterkaitan antara IT - Related Goals yang menjadi objek dengan Enterprise Goals yang terpilih pada COBIT 5 sangat kuat, maka diberi tanda "P" yang berarti primary. Jika terdapat hubungan yang tidak dominan, maka diberi tanda " $S$ " yang berarti secondary. Jika tidak ada hubungan sama sekali maka dikosongkan. Pemetaan enterprise goal dengan itrelated goal disajikan pada Gambar 4 dan Gambar 5. 


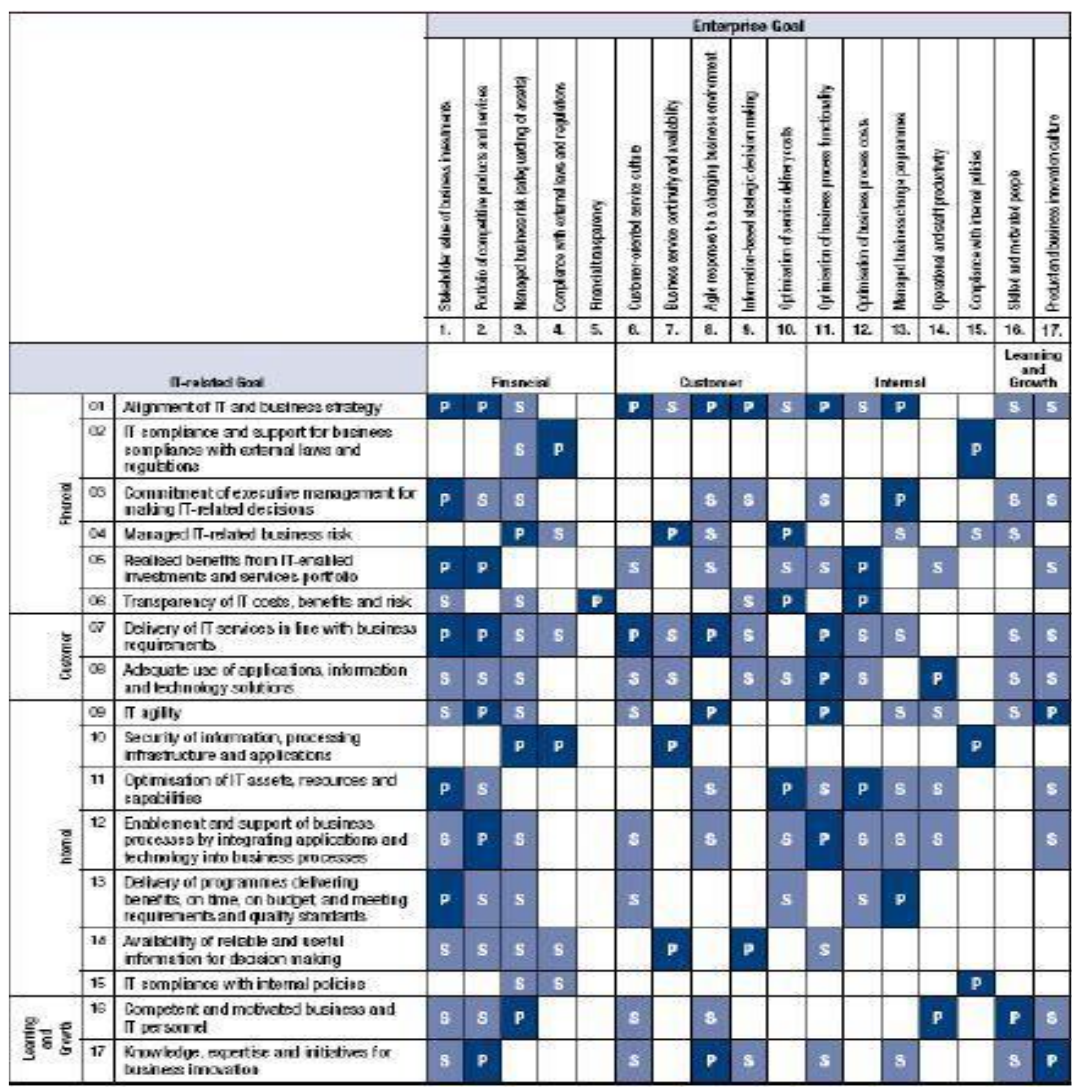

Gambar 4. Pemetaan Enterprise Goal dengan IT-Related Goal

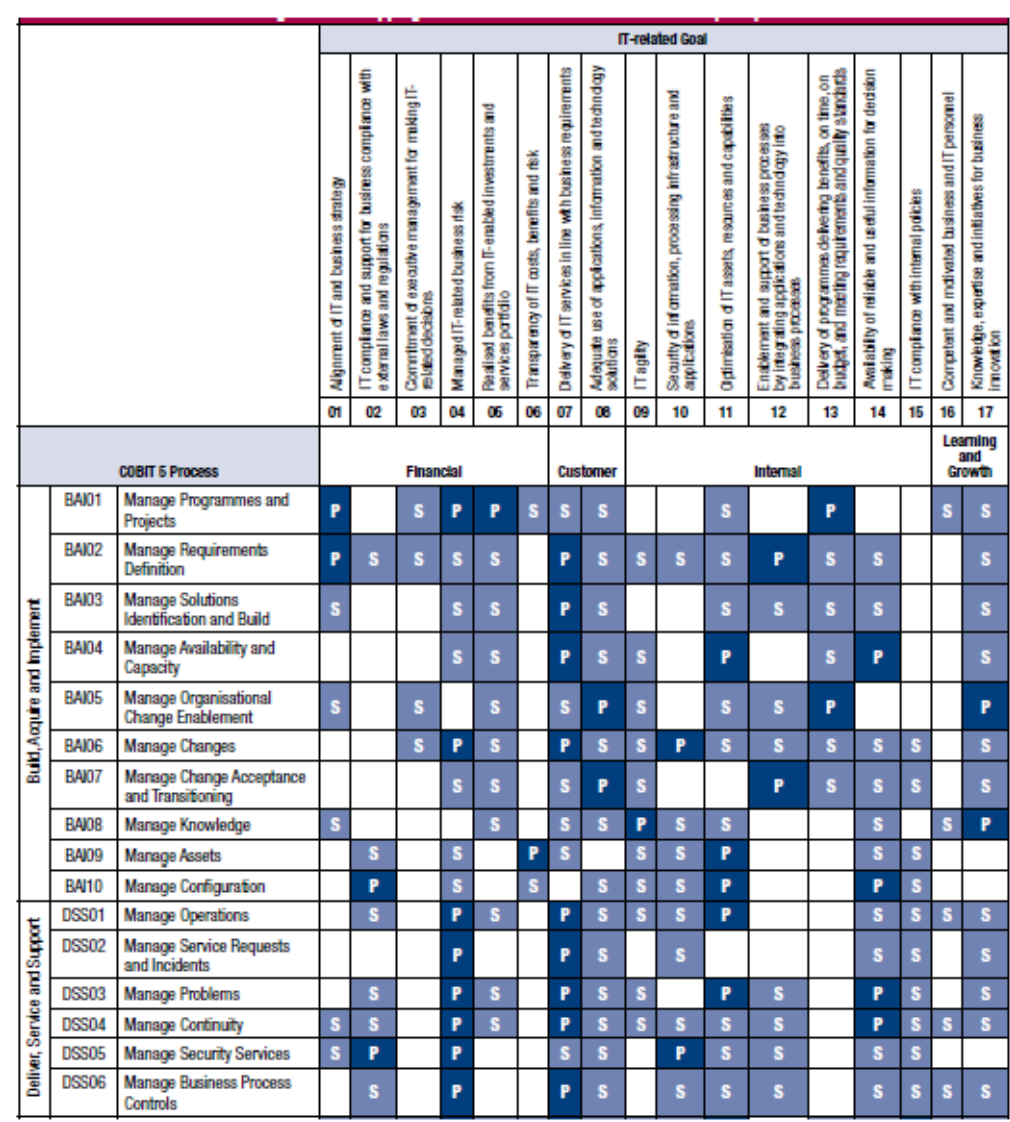

Gambar 5. Pemetaan IT - Related Goals dengan Proses domain DSS 
Pemetaan dilakukan untuk mendapat proses - proses domain DSS mana sajakah yang masuk dalam ruang kegiatan audit. Setiap tujuan TI memiliki masing-masing proses TI yang relevan. Setelah dilakukan mapping terhadap tujuan bisnis perusahaan dengan tujuan TI, selanjutnya dilakukan mapping tujuan TI dengan proses TI.

\subsection{Diagram RACI}

Diagram RACI adalah bagian dari Responsibility Assignment Matrix (RAM), yaitu bentuk pemetaan antara sumberdaya dengan aktivitas dalam setiap prosedur. RACI merupakan singkatan dari R (Responsible), A (Accountable), C (Consulted), dan I (Informed). Untuk melakukan penilaian dengan domain DSS, maka dilakukan mapping antara sub control objectives dan sumber daya manusia yang ada pada pelaksaan sistem informasi. Berikut contoh dari diagram RACI pada DSS04. Diagram RACI disajikan pada Gambar 6.

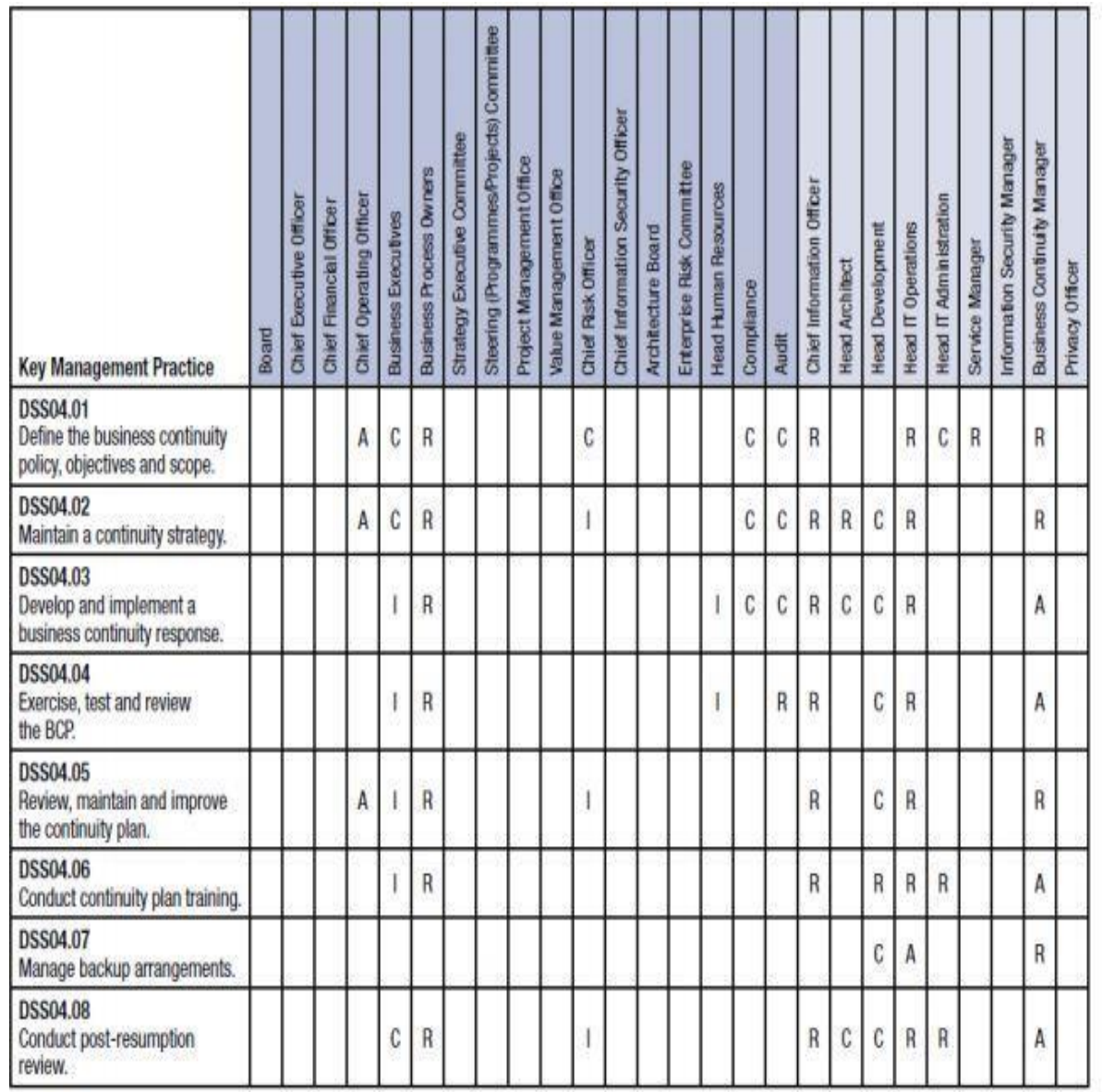

Gambar 6. Diagram RACI

Mapping tersebut dilakukan untuk seluruh control objective yang ada pada domain DSS. Dalam mapping tersebut diberi suatu nilai berupa R/A/C/I, yang memiliki arti:

a. $\mathrm{R}$ (Responsible), berarti bahwa bagian tersebut merupakan pihak pelaksana yang harus bertanggung jswab melaksanakan dan menyelesaikan aktivitas yang menjadi tanggung jawabnya.

b. A (Accountable) berarti bahwa bagian tersebut merupakan pihak yang harus mengarahkan jalannya pelaksanaan aktivitas.

c. $\quad \mathrm{C}$ (Consulted) berarti bahwa bagian tersebut merupakan pihak yang akan menjadi tempat konsultasi selama pelaksanaan aktivitas.

d. I (Informed) berarti bahwa bagian tersebut merupakan pihak yang diberikan infromasi mengenai pelaksanaan aktivitas. 


\subsection{Hasil Analisis Data Dengan COBIT}

Tahap awal pelaksanaan audit ini adalah pengumpulan data, untuk mendukung penilaian, evaluasi lapangan dan juga untuk mengetahui kondisi nyata dari Direktorat SISFO terhadap audit yang dilakukan. Pengumpulan data dilakukan melalui kuisioner, wawancara, dan survey lapangan. Dalam pengumpulan data melalui kuisioner dan wawancara ini dilakukan berdasarkan tabel Raci Chart yang sudah dipetakan dengan struktur organisasi di Politeknik X. Pada tahap ini, dilakukannya kuisioner untuk mencari tanggapan - tanggapan dari para responden mengenai kondisi terkini yang ada pada Direktorat SISFO terkait dengan domain DSS (Deliver, Service and Support). Kuisioner ini berisikan pertanyaan pertanyaan yang sesuai dengan proses - proses yang ada pada Domain DSS (Deliver,Service and Support).

Pada tahap wawancara ini, dilakukan untuk mengkroscek/mencari kebenaran dari tanggapan tanggapan pada kuisioner yang telah di dapat, dan juga untuk memperoleh bukti - bukti yang terkait dengan domain DSS (Deliver, Service and Support). Wawancara dilakukan secara face to face dengan responden, dan juga didokumentasikan dengan rekaman wawancara. Prosedur pengumpulan data disajikan pada Gambar 7.

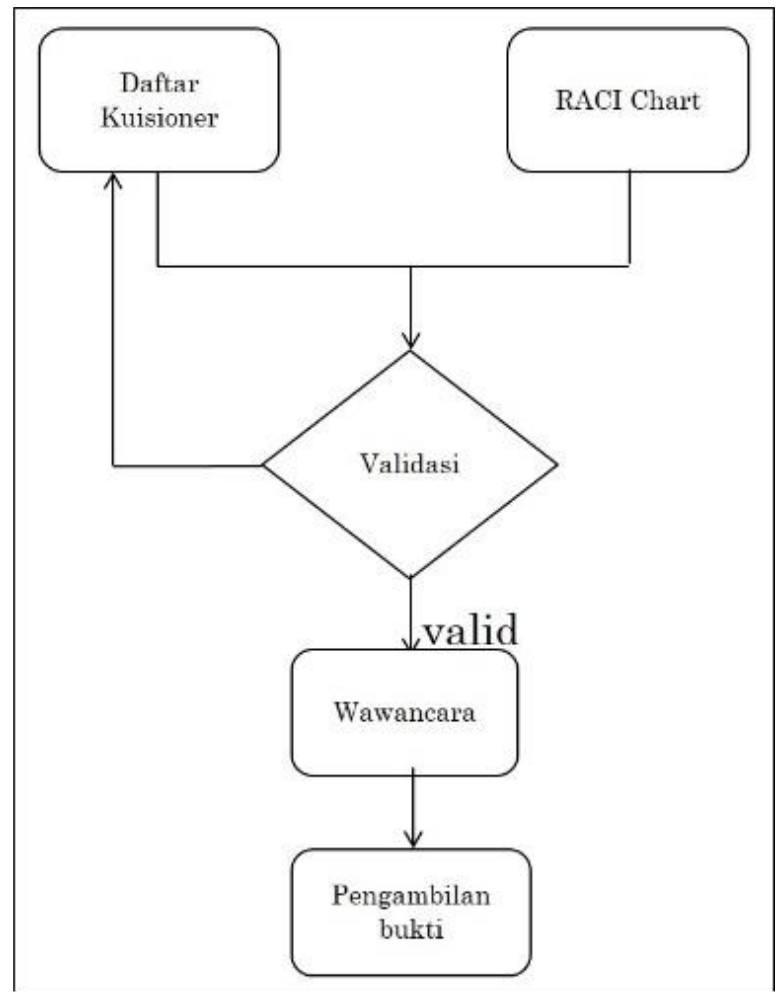

Gambar 7. Prosedur Pengumpulan Data

Dalam pengumpulan data terdapat langkah tersendiri, berikut adalah langkah - langkah peneliti untuk melakukan pengumpulan data Langkah awal dari pengumpulan data ini mulai dari menyiapkan daftar kuisioner, kemudian di sesuai atau di petakan dengan hasil diagram RACI supaya daftar kuisoner tepat dengan sasaran. Setelah itu melakukan validasi hasil kuisioner, apabila data kuisioner ada yang tidak valid maka kuisioner yang tidak valid diulang kembali sampai menghasilkan hasil valid. Kemudian setelah semua data valid maka dilakukan kroscek dengan melakukan wawancara ke pihak yang memiliki jabatan tinggi di Direktorat SISFO, kemudian disertai dengan pengambilan bukti.

Langkah awal dari pengumpulan data ini mulai dari menyiapkan daftar kuisioner, kemudian di sesuai atau di petakan dengan hasil diagram RACI supaya daftar kuisoner tepat dengan sasaran. Setelah itu melakukan validasi hasil kuisioner, apabila data kuisioner ada yang tidak valid maka kuisioner yang tidak valid diulang kembali sampai menghasilkan hasil valid. Kemudian setelah semua data valid maka dilakukan kroscek dengan melakukan wawancara ke pihak yang memiliki jabatan tinggi di Direktorat SISFO, kemudian disertai dengan pengambilan bukti Pengukuran data digunakan untuk menilai apakah hasil dari kuisioner tersebut dapat dipercaya atau valid. Dalam teknik pengukuran data disini 
menggunakan validasi. Jenis - jenis dari validasi pun bermacam - macam, disini penulis mneggunakan jenis validasi korelasi product moment yang di kemukakan oleh pearson.

Pemilihan jenis validasi dengan korelasi product moment ini dirasa cocok karena instrument yang digunakan dalam pengukuran validasi ini serupa (menggunakan variable interval), dan cara perhitungan yang dapat diterapkan dengan baik. Pada validasi korelasi product moment ini item dikatakan valid jika nilai-nilai Total Correlation lebih besar dari nilai kritis. Nilai r-kritis yang ditetapkan adalah sebesar 0,30 item pertanyaan yang memiliki nilai koefisien validitas lebih besar dari nilai $r$ kritisnya dapat disimpulkan bahwa item tersebut valid dalam yang berarti bahwa item yang digunakan untuk mengukur suatu kajian dalam Direktorat SISFO dalam domain DSS (Deliver, Service and Support) menghasilkan data yang valid/dapat dipercaya.

\subsection{Rekapitulasi Nilai Capability}

Dalam menentukan kondisi pada level manakah aktifitas - aktifitas yang terdapat pada form kerja audit itu berada, maka dilakukan analisis berupa mencari level yang tepat pada form hasil kuisioner. Penentuan level ditiap aktifitas ini dilakukan dengan memilih nilai modus atau nilai yang paling banyak muncul pada tiap aktifitasnya. Dan apabila nilai yang muncul itu terdapat 2 level atau mungkin lebih, maka yang di pilih adalah nilai level yang terkecil diantaranya, misalkan pada DSS01-01 pada aktifitas ke 3 terdapat 9 responden, kemudian dari 9 responden yang memilih di level 2 adalah 4 orang, di level 4 adalah 4 orang, dan di level 5 adalah 1 orang. Maka level yang terpilih adalah pada level 3, karena diartikan juga berarti 4 orang yang memilih di level 4 tersbut juga merasa bahwa pada aktifitas ke 3 telah berada pada level 3 .

Setelah dilakukan analisis hasil kuisoner maka di dapatkanlah hasil nilai - nilai pada tiap aktifitas yang ada pada domain DSS (Deliver, service, and Support) dan di masukan ke dalam form kerja audit. Tindakan selanjutnya yang dilakukan adalah mencari rata - rata nilai pada tiap proses untuk mengetahui bagaimana kondisi tiap proses yang ada. Berikut adalah hasil rekapitulasi nilai proses pada domain DSS (Deliver, Service, and Support).

Politeknik X memiliki sistem informasi akademik berbasis visual yang dapat diakses secara LAN. Sistem informasi pengelolaan tingkat layanan tata kelola TI ini dibangun dengan platform Bahasa Pemrograman Visual Basic dan dengan dukungan database Microsoft SQL. Secara umum tata kelola TI saat ini dapat dilihat dari hasil perhitungan tingkat kematangan (maturity level) tata kelola TI untuk sistem informasi pengelolaan tingkat layanan pada sistem informasi akademik Pada tabel 1 berikut akan disampaikan hasil rekapitulasi tingkat kematangan (maturity level) untuk domain DS. Maturity level disajikan pada Tabel 2. Sedangkan grafik maturity level disajikan pada Gambar 8

Tabel 2. Maturity Level

\begin{tabular}{llcc}
\hline \multicolumn{1}{c}{ Proses Domain } & Level Rata-Rata & $\begin{array}{c}\text { Pembulatan } \\
\text { Level }\end{array}$ \\
\hline DSS-01 Mengelola Operasi & 3.42 & 3 \\
DSS-02 Mengelola Permintaan & Layanan dan & 3.35 & 3 \\
Mengelola Insiden & & 3.15 & 3 \\
DSS-03 Mengelola Masalah & 2.85 & 2 \\
DSS-04 Mengelola Keberlanjutan & 3.24 & 3 \\
DSS-05 Mengelola Layanan Keamanan & 3.32 & 3 \\
DSS-06 Mengelola Kontrol-Kontrol Proses Bisnis & \\
\hline
\end{tabular}




\section{Maturity Level}

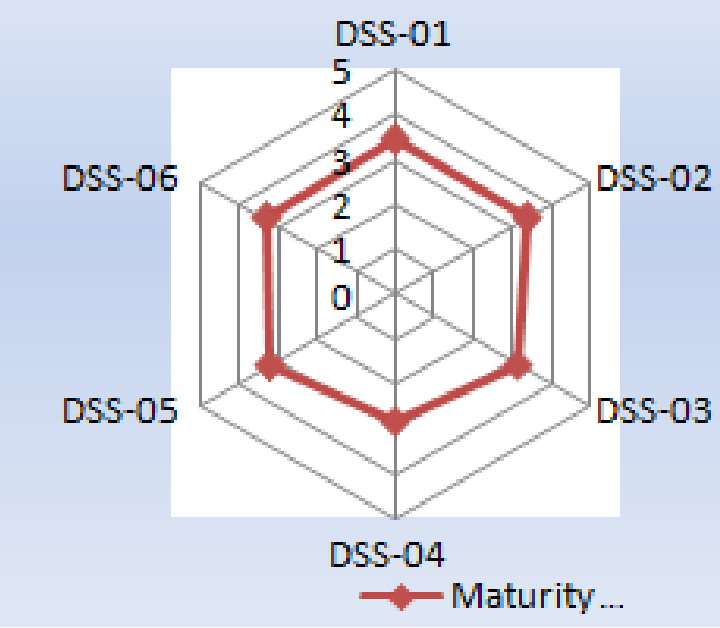

Gambar 8. Grafik Maturity Level

Dari capability level yang didapat 3.42 dilakukan pembulatan untuk memudahkan mencari kondisi terkini berdasarkan criteria capability level yang telah ditetapkan. Dalam melakaukan pembulatan tersebut menggunakan konsep penentuan capability process tertentu, yaitu suatu proses akan mencapai level k jika semua atribut sebelum level $\mathrm{k}$ terpenuhi secara fully achieved dan semua atribut di level $\mathrm{k}$ telah terpenuhi secara largely (>50\% hingga $85 \%$ ) atau fully achieved (>85\%). Disini penulis menggunakan pilihan yang terpenuhi secara fully achieved atau level terpenuhi dengan nilai $>85 \%$, yang di rasa akan lebih akurat dalam menilai atau menggambarkan kondisi yang existing yang ada.

\subsection{Pengumpulan Evidence dan Kondisi Existing}

Dalam penentuan suatu kondisi yang di dapat sudah valid atau belum, dalam audit ini dilakukan dengan pengumpulan bukti - bukti yang sudah ditetapkan pada COBIT 5 Domain DSS (Deliver, Service, and Support). Hasil bukti yang di dapat diperiksa dengan kesesuaiaan kondisi existing yang telah dapat dan menjadi alat ukur tersendiri. Berdasarkan audit yang dilakukan pada lingkung domain DSS, maka didapatlah kondisi existing dari DSS01:

a. Menjalankan manajemen akademik dan rekap dilakukan dengan baik.

b. Dalam menjalankan prosedur operasional telah dilakukan dengan baik, dan ada beberapa aktivitasaktivitas tertulis di Standard Operating Procedure (SOP) dan roadmap yang berdasarkan deadline dan kebutuhan akademik

c. Tidak asuransi independent terhadap manajemen outsourced IT service.

d. Pelaksanaan monitoring infrastruktur software akademik terlaksana dengan baik.

e. Dalam manage environtment Direktur menjalankan kehendak sesuai dengan yang di tetapkan oleh Bagian Akademik.

f. Dalam menjaga fasilitas yang dimiliki, tidak ada penilaian terhadap fasilitas yang ada. Dalam pengawasan fasilitas disak ada yang mengawasi, terdapat CCTV tapi tidak ada orang yang menjaganya.

Berdasarkan audit yang dilakukan pada lingkung domain DSS, maka didapatlah kondisi existing dari DSS02:

a. Dalam menjalankan layanan insiden dan permintaan layanan telah dibuatkan skema layanan/ SOP tentang request insiden.

b. Terdapat aturan - aturan mengenai penanganan insiden, dan telah di dokumentasikan dalam bentuk SLA.

c. Direktur tidak memiliki akses langsung terhadap aplikasi sistem informasi akademik hanya menerima laporan daru pihak akademik.

d. Aplikasi sistem informasi yang dimiliki dapat digunakan untuk menyimpan data akademik masuk, akademik keluar, dan stock akademik serta memberikan laporan akademik dengan baik.

e. Pada aplikasi tersebut insiden yang diterima di alokasikan ke bagian yang 
f. sesuai untuk menanganinya.

g. Ada yang memonitoring bagaimana tindakan terhadap insiden yang ada dari

h. helpdesk Bagian Akademik.

i. Dilakukannya pelaporan saat rapat tiap 1 bulan terhadap insiden - insiden yang ada.

Berdasarkan audit yang dilakukan pada lingkung domain DSS, maka didapatlah

kondisi existing dari DSS03:

a. Kepala Bagian Akademik melakukan pengklasifikasian terhadap permasalahan yang muncul.

b. Permasalah yang ada di rekap dan dilaporkan dalam rapat besar tiap 1 bulan Kepala Akademik

c. Melakukan investigasi dan mendiagnosa masalah - masalah yang timbul, namun pendokumentasiannya tidak dijaga, jadi hanya terdokumentasi dalam notulensi RTM (Rapat Tinjauan Manajemen).

d. Terdapat pencatatan dari kejadian eror terhadap aplikasi sistem akademik, dan juga dilaporkan saat rapat

e. Dalam menyelesaikan masalah dan menutup masalah dikomunikasikan dalam RTM dan dilakukan dengan baik, direkap dan dijaga dengan baik.

Berdasarkan audit yang dilakukan pada lingkung domain DSS, maka didapatlah kondisi existing dari DSS04:

a. Direktur membuat kebijakan terhadap keberlangsungan proses bisnis dengan melakukan kesepakatan terhadap Bagian Akademik dan kemudian disetujui oleh Kepala Bagian Akademik

b. Kepala Bagian Akademik membuat antisipasi terhadap ganguan dari skenario insiden yang ada dengan meresolusi gangguan secara teknis dan menyelesaikan gangguan non teknis dengan kebijakan

c. Dilakukanya pemantauan/penilaian terdahap proses bisnis yang berlangsung

d. Untuk menjaga keberlangsungan strategi dalam proses bisnis terlebih dahulu dilakukan analisis pengaruh/dampak yang terjadi dengan kesiapan dan ketetapan di Bagian Akademik dan pilihan strategi yang ada di komunikasikan dengan pihak lainya

e. Tidak dilakukannya Bussines Plan Continuity untuk pengembangan implementasi proses bisnis di Bagian Akademik, hal ini sedang dalam tahap perencanaan, belum berlangsung.

f. Dalam menejemen backup dilakukannya test terlebih dahulu, kemudian hasil dilaporkan setelah itu baru digunakan secara tetap.

g. Melakukan review terhadap kegiatan proses bisnis dan membuat daftar - daftar perubahan terhadap perencanaan yang telah disusun dalam RTM.

Berdasarkan audit yang dilakukan pada lingkung domain DSS, maka didapatlah kondisi existing dari DSS05 :

a. Ada aturan tertulis dalam aktivitas-aktivitas untuk melindungi fasilitas dari maleware, namun dokumen tidak dijaga.

b. Melakukan riset terhadap ancaman - ancaman yang potensial.

c. Dibuatnya kebijakan mengenai keamanan konektifitas dan perangkat endpoint.

d. Dalam manjemen hak akses dilakukannya pembuatan hak akses pada software, kemudian dimonitorng. Apabila ada permintaan hak akses maka permintaan harus di disposisi.

e. Terdapat pemantauan dari aktifitas pengaksesan pada software akademik

f. Setiap perangkat sensitive dan perangkat - perangkat yang ada di inventariskan dengan baik kebagian logistic.

g. Dibuatkannya daftar hask akses yang istimewa berdasarkan struktural

h. Terdapat penentuan karakteristik keamanan dalam memonitoring keamanan infrastruktur yang di tentukan dalam rapat dan terdapat security incident dalam sistem informasi akademik.

Berdasarkan audit yang dilakukan pada lingkung domain DSS, maka didapatlahkondisi existing dari DSS06 :

a. Penyelarasan aktivitas kontrol yang ada di proses bisnis dengan tujuan

b. Aktivitas akademik sudah berlangsung baik. Dilengkapi laporan tinjuan dan juga analisis terhadap akar permasalahan yang muncul

c. Pemantauan dilakukan terus - menerus namun tidak terdapat dokumentasinya.

d. Peran, tanggungjawab, hak akses dan level otoritas telah didefinisikan dan terdokumentasi dalam sistem dashboard yang bersifat private.

e. Telah dilakukannya koreksi yang dilakukan oleh pihak manajemen untuk mengetahui kesalahan kesalahan kemudian dianalisisdilaporkan saat Rapat.

f. Terdapat rekaman di sistem informasi helpdesk yang dapat digunakan untuk memastikan jejak kegiatan informasi dan pertanggung jawabannya. 
g. Tidak adanya laporan mengenai daftar - daftar pelangaran terhadap sistem yang padahal dilakukan analisisnya.

\subsection{Analisi Gap}

Analisis Gap ini dlakukan untuk mencari selisih dari level capability yang didapat dengan level target yang ingin dicapai. Dalam penentuan level target, ditentukan dengan level yang sedang dituju dari level rata - rata yang didapat. Contoh untuk DSS01 di peroleh level rata - rata 3,42 maka DSS01 sedang dalam tahap menuju level capability 4 dan masih mencapai 0,42 atau 42\% di atas level 3 atau kurang dari 0,58 atau 58\% menuju level capabilty 4. Sehingga ditetapkan level targetnya adalah level 4. Berikut ini adalah hasil dari pelaksanaan audit, diperolehnya hasil capability level untuk keseluruhan proses. Hasil analisis GAP disajikan pada Tabel 3.

Tabel 3. Analisis GAP

\begin{tabular}{cccc}
\hline Proses Domain & Level Existing & Level Target & Gap \\
\hline DSS-01 & 3.42 & 4 & 0.58 \\
DSS-02 & 3.35 & 4 & 0.65 \\
DSS-03 & 3.15 & 4 & 0.85 \\
DSS-04 & 2.85 & 3 & 0.15 \\
DSS-05 & 3.24 & 4 & 0.76 \\
DSS-06 & 3.32 & 4 & 0.68 \\
\hline
\end{tabular}

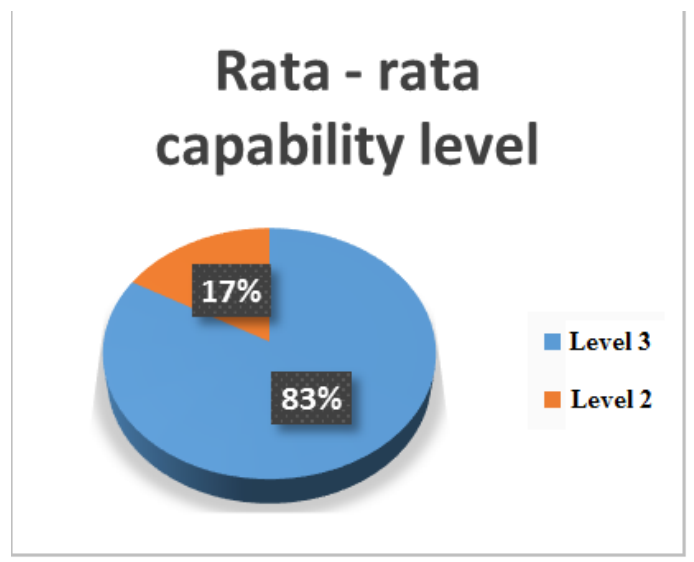

Gambar 9. Rata-Rata Capability Level

Dari Tabel 3 diperoleh capability level tiap-tiap proses domain DSS COBIT 5, dari gambar 9 .6 dapat diketahui bahwa rata-rata capability level yang diperoleh berada pada level 3 yaitu Establsh Process. Artinya aktivitas-aktivitas telah dilakukan, ada standar penerapan dalam melakukan proses tersebut, terdokumentasi dan komunikasi berjalan dengan baik.

\subsection{Rekomendasi}

Berdasarkan analisis Gap yang di dapat dengan level target yang ingin dicapai pada DSS01, maka berikut adalah beberapa rekomendasi yang dapat penulis berikat untuk meningkatkan kualitas Sistem Informasi Akademik :

a. Menindak lanjuti hasil audit independent terhadap kualitas layanan, lingkungan dan dengan pihak luar yang menjalin kerjasama, apabila dari audit independent tidak ada maka ditambahkan sendiri.

b. Melakukan analisis perangkat IT untuk mencegah ancaman yang timbul dari tindakan manusia seperti pencurian, dan juga terlindung dari ancaman dari hal - hal lain misalkan kebocoran, akan hujan, bahaya kebakaran karena konsleting di Akademik.

c. Melakukan penilaian terhadap infrastruktur yang dimilki dan dibuat dokumentasinya untuk bahan evaluasi kedepan.

d. Menjaga dan memonitoring infrastruktur dengan baik, karena telah disediakan CCTV namun tidak ada yang menoperasikannya, lebih baik disediakan pegawai yang bertugas untuk memonitoringnya, misalkan satpam. 
e. Menetapkan dan menyetujui mutu layanan untuk semua software akademik berdasarkan kebutuhan.

f. Mengawasi dan melaporkan pencapaian mutu layanan secara terus menerus dan laporan diberikan dalam bentuk formal.

g. Meninjau kontrak dan persetujuan mutu layanan secara teratur untuk memastikan efektifitas, hal-hal baru dan apabila ada perubahan-perubahan maka disertai dengan penjelasan.

Berdasarkan analisis Gap yang di dapat dan dengan level target yang ingin dicapai pada DSS02, maka berikut adalah beberapa rekomendasi yang dapat penulis berikat untuk meningkatkan kualitas Sistem Informasi Akademik :

a. Membuat klasifikasi terhadap akademik yang dibutuhkan sehingga mudah untuk dipetakan ke bagian atau divisi yang akan langsung menyelesaikan.

b. Membuat strategi - strategi dalam permintaan layanan akademik dan pemecahan insiden baik dalam bentuk kebijakan ataupun tindakan penanganan langsung seperti sistem.

c. Melakukan review terhadap software yang dibuat minimal tiap satu tahun untuk mengetahui ketidaksesuaian yang terjadi dan melukan inovasi terhadap software yang sudah ada.

d. Memberikan wadah untuk kritik dan saran kepada mahasiswa untuk menilai pelayanan, kepuasan mahasiswa dan pengembangannya.

e. Membuat inovasi strategi terhadap insiden yang belum terselesaikan, menganalisis dan mengevaluasi kembali inovasi strategi yang dibuat.

f. Membuat dokumentasi terhadap resolusi atau solusi alternative terhadap pemecahan insiden dan mengevaluasinya.

g. Mengembangkan sistem yang dapat melaporkan kecenderungan masalah atau insiden yang dihadapi sehingga pihak Akademik dapat mengetahui kesalahan - kesalahan yang didapatkan.

h. Mendefinisikan batas waktu pemecahan dalam klasifikasi insiden dan mengevaluasi minimal tiap bulan sekali.

i. Mengidentifikasikan provider serta mengenali kategori layanan

j. Mengenali dan mengurangi resiko-resiko terkait kemampuan bagian akademik dalam memberikan layanan ketersediaan akademik dengan cara efisien dan aman secara terus-menerus.

k. Mendokumentasikan semua kontrak kerja dengan provider dan meninjaunya dengan berkala.

Berdasarkan analisis Gap yang di dapat dan dengan level target yang ingin dicapai pada DSS03, maka berikut adalah beberapa rekomendasi yang dapat penulis berikat untuk meningkatkan kualitas Sistem Informasi Akademik:

a. Melakukan pemantauan terhadap kinerja penyelesaian masalah yang telah ditentukan.

b. Mendokumentasikan dan mengalisa kembali laporan masalah yang ada baik yang sudah terselesaikan maupun yang belum terselesaikan.

c. Menganalisa akar - akar permasalahan yang muncul dan pemecahan masalah, kemudian mendokumentasikannya supaya tidak terjadi masalah yang sama.

d. Membuat sistem/skema yang dapat mengetahui jalannya penyelesaian pemecahan masalah yang ada agar dapat dipantau oleh pihak atasan.

e. Membuat dokumentasi terkait solusi - solusi dalam pemecahan masalah.

f. Melakukan analisa pembiayan untuk menyelesaikan masalah, melakukan pemantauan dan didokumentasikan.

g. Membuat analisa pengalokasian sumberdaya yang akan digunakan untuk mengoptimalkan resource yang dimiliki.

h. Membuat proses perencanaan untuk peninjauan kapasitas dan kinerja software akademik.

i. Meninjau kinerja dan kapasitas kinerja software akademik ini

j. Melakukan ramalan kinerja dan kapasitas sumber daya TI secara berkala untuk memperkecil resiko gangguan layanan karena penurunan kinerja dan kapasitas. Ramalan ini juga dijadikan sebagai masukan pada perencanaan kinerja dan kapasitas selanjutnya.

k. Ketersediaan sumber daya dipantau dalam mendukung kinerja dan kapasitas

1. Mendokumentasikan semua proses, melaporkan da mengawasi kinerja dan kapasitas software akademik secara terus menerus.

Berdasarkan analisis Gap yang di dapat dan dengan level target yang ingin dicapai pada DSS04, maka berikut adalah beberapa rekomendasi yang dapat penulis berikat untuk meningkatkan kualitas Sistem Informasi Akademik: 
a. Melakukan pengukuran keberlangsungan proses pengolahan data akademik untuk mengetahui tingkat kematangannya dan kesenjangan prosesnya, didokumentasikan dan dievaluasi.

b. Mengukur kesesuaian kebijakan yang dibuat dalam keberlangsungan proses pengolahan data akademik.

c. Menganalisis dan membuat skema atau SOP tentang terjadinya gangguan dalam sekenario proses pengolahan data akademik yang ditetapkan.

d. Melakukan evaluasi terhadap kebutuhan keberlanjutan proses pengolahan data akademik yang berlangsung

e. Menetapkan ukuran - ukuran terhadap ancaman - ancaman yang dapat menggangu jalannya proses akademik.

f. Membuat skema atau sistem yang berisi respon terhadap insiden dan kominukasinya, mendokumentasikan dan dievaluasi.

g. Membuat business continuity plan (BCP) untuk pengembangan proses akademik dan dokumentasikan.

h. Melakukan pengukuran dan evaluasi terhadap tujuan pelatihan.

i. Melakukan penjaminan keamanan terhadap distribusi data yang bersifat rahasia.

j. Membuat ketetapan ukuran - ukuran untuk pengambangan latihan sumberdaya manusia yang dimiliki, dan dipantau keberlangsungannya.

k. Aspek keamanan dan keberlangsungan sistem

a. Confidentiality: akses terhadap data/informasi dibatasi hanya bagi mereka yang punya otoritas

b. Integrity: data tidak boleh diubah tanpa ijin dari yang berhak

c. Authentication: untuk meyakinkan identitas pengguna system

d. Availability: terkait dengan ketersediaan layanan

1. Membuat perencanaan TI yang dirancang untuk mengurangi dampak gangguan utama pada proses dan fungsi bisnis utama

m. Memelihara perencanaan kelancaran TI untuk memastikan bahwa perencanaan kelancaran tetap terjaga dan terbaru dan terus menerus mencerminkan kebutuhan akademik.

n. Melakukan pelatihan perencanaan kelancaran sistem informasiakademik mengenai prosedurprosedur, peran dan tanggung jawabnya apabila terjadi masalah atau bencana, serta terdistribusi dan tersedia bagi siapa saja yang membutuhkan

Berdasarkan analisis Gap yang di dapat dan dengan level target yang ingin dicapai pada DSS05, maka berikut adalah beberapa rekomendasi yang dapat penulis berikat untuk meningkatkan kualitas Sistem Informasi Akademik:

a. Membuat kebijakan terkait dengan maleware software, didokumentasikan dan dievaluasi. (mis: menginstall antivirus yang diwajibkan)

b. Menetapkan sistem yang digunakan untuk mengevaluasi ancaman - ancaman yang akan timbul, didokumentasikan dan dimonitoring.

c. Melakukan evaluasi yang dilakukan rutin, minimal tiap semester terhadap sistem informasi yang dikhawatirkan dapat timbul potensi ancaman baru.

d. Memberikan peringatan kepada semua pegawai akan kedasarannya terhadap keamanan sistem dan perangkat yang dimiliki.

e. Membuat laporan mengenai ujicoba sistem keamanan yang diterapkan dan dievaluasi.

f. Mengukur kualitas sistem keamanan dan hak akses yang diberikan.

g. Mengevaluasi atau memantau hak akses yang diberikan untuk terjaga dari ancaman - ancaman yang potensial.

Berdasarkan analisis Gap yang di dapat dan dengan level target yang ingin dicapai pada DSS06, maka berikut adalah beberapa rekomendasi yang dapat penulis berikat untuk meningkatkan kualitas Sistem Informasi Akademik:

a. Menetapkan ukuran - ukuran goal dari proses bisnis, mendokumentasikan dan dievaluasi.

b. Membuat laporan dari kontrol pemrosesan agar mudah diketahui gejala - gejala yang timbul.

c. Memantau dan mengevaluasi prosedur keamanan untuk melindungi aset informasi.

d. Membuat kebijakan dalam penentuan peran yang berwenang untuk mengakses aktivitas atau data yang bersifat sensitive, dijelaskan secara rinci dan didokumentasikan.

e. Mereview penyimpangan - penyimpangan yang terjadi dalam keberlangsungan prose bisnis, mendokumentasikan dan dievaluasi

f. Membuat kebijakan terhadap pemberian hukuman kepada pegawai yang melakukan pelanggaran pelanggaran dalam pemantauan kegiatan proses bisnis. 
g. Menyimpang dengan baik atau mengarsipkan data seperti sumber informasi, rekaman transaksi untuk dijadikan bukti dalam pengukuran penilaian keberlangsungan proses bisnis dan dapat sebagai rekomendasi.

h. Mengidentifikasi jenis - jenis data yang bersifat rahasia, membuat prosedur penyimpanan dan penghapusan yang tepat.

Sebelumnya telah dituliskan beberapa rekomendasi yang berdasar pada tiap proses yang ada pada domain DSS (Deliver, Service, and Support). Berikut ini beberapa tambahan rekomendasi secara umum berdasar kondisi Direktorat SISFO dalam ruang lingkup iGracias. Capability level yang didapat secara keseluhan adalah level 3 Established Process, level target yang ingin dicapai adalah 4 redictable process, sehingga rekomendasi yang disusun adalah sebagai berikut:

a. Membuat penerapan pengukuran layanan yang harus dipenuhi dalam tiap proses bisnis untuk terjaminnya sistem informasi akademik berjalan dengan baik.

b. Membuat sistem monitoring dan evaluasi yang tepat terhadap proses bisnis untuk mengoptimalkan keberlangusngan sistem informasi akademik.

c. Membuat dokumentasi atau laporan mengenai keseluruhan hasil proses yang berlangsung, dan juga pelanggaran yang terjadi sebagai bahan evaluasi dan pengembangan keberlanjutannya.

d. Membuat dan menjaga dengan baik pendokumentasian informasi yang dapat meningkatkan/menjaga keberlangsungan jalannya sistem sistem informasi akademik..

\section{KESIMPULAN}

Berdasarkan audit yang dilakukan pada Direktorat SISFO akademik Politeknik X framework COBIT 5 Domain DSS (Deliver, Service, and Support) maka kesimpulan dari penelitian ini adalah:

a. Pada tahap Pra audit telah diperoleh 6 proses domain DSS COBIT 5 yang dimana merupakan keseluruhan proses dari domain DSS yang sesuai dengan kondisi tata kelola sistem informasi akademik di Politeknik X dan digunakan sebagai ruang lingkup dan standar audit yaitu DSS01, DSS02, DSS03, DSS04, DSS05, dan DSS06.

b. Dari hasil audit, diketahui ada 1 proses yang mempunyai level kapabilitas 4 yaitu DSS02, ada 5 proses yang mempunyai level kapabilitas 3 yaitu DSS01, DSS03, DSS04, DSS05 dan DSS06.

c. Menurut level kapabilitas masing-masing proses, ditentukan level target masing-masing proses yaitu berupa 1 level di atas level kapabilitas,yang ditentukan berdasar analisis dan juga persetujuan dengan stakeholder, sehingga didapat level target untuk DSS01, DSS03, DSS04, DSS05 dan DSS06 adalah level 4, untuk DSS02 adalah level 5.

d. Level capability keseluruhan yang diperoleh berdasarkan keseluruhan rata - rata adalah 3 , yang berarti sebagian besar aktifitas pada domain DSS untuk sistem informasi akademik di Politeknik X telah dilakukan, ada standar penerapan dalam melakukan proses tersebut, terdokumentasi dan komunikasi berjalan dengan baik.

\section{REFERENSI}

1. Effendi, D. (2008). Perancangan IT Governance Pada Layanan Akademik di UNIKOM (Universitas Komputer Indonesia) Menggunakan COBIT (Control objective For Information dan Related Technology) Versi 4.0).

2. Fitroh. 2012. Penilaian Tingkat Kematangan Tata Kelola TI Pada Sistem Informasi Manajemen Akademik. Jurnal Seminar Nasional Teknologi Informasi 2012 (SNTI 2012). ISSN : 1907 5022.Universitas Islam Negeri Jakarta. Jakarta

3. Hendriadi, a. A. (2012). Pengukuran Kinerja Sistem Informasi Akademik Dengan Menggunakan Kerangka Kerja Cobit 4.1 Pada Domain Plan And Organise Di Universitas Singaperbangsa Karawang. Majalah ilmiah solusi, 10

4. Hermanto, d., \& ricoida, d. I. (2014). Analisis pengukuran tingkat kematangan menggunakan kerangka cobit 4.1 (studi kasus: pt smi). Sesindo 2014.

5. Jusuf, H. (2009). IT Governance pada Layanan Akademik On-Line di Universitas Nasional Menggunakan COBIT (Control Objectives For Information and Related Technology) versi 4.0. In Seminar Nasional Aplikasi Teknologi Informasi (SNATI).

6. Maria, E. (2011). Perbandingan Sistem Informasi Akademik Universitas Satya Wacana menggunakan Cobit Framework. Jurnal Fokus Ekonomi, 10

7. Mulyana, d. Pengukuran Tingkat Maturity Tata Kelola Sistem Informasi Akademik Dengan Kerangka Kerja Cobit ${ }^{8}$.1 Di Smkn 1 Kawali-Ciamis.

8. Ricoida, D. I. (2008). Perancangan Tata Kelola TI Untuk Peningkatan Layanan Sistem Informasi Akademik: Studi Kasus STMIK MDP. @ lgoritma, 4(2), 1-6. 
9. Rizka, L., Indah, U., \& Wardati. Sistem Informasi Akademik Berbasis Web Pada Lembaga Bimbingan Belajar Be Excellent Pacitan, Vol 2, No 2 (2013):IJNS April 2013

10. Sarno, R., \& Herdiyanti, A. (2010). Developing Information Technology Policies For Enterprise Resource Planning To Improve Customer Orientation And Service. International Journal of Computer Science and Network Security, 10, 82-94.

11. Setiawan, H. (2014). IT Governance \& Penggunaan COBIT Framework. Jurnal Sistem Informasi, 2(2). Journal Speed - Sentra Penelitian Engineering dan Edukasi - Volume 8 No 1 - 2016 speed.web.id ISSN : 1979-9330 (Print) - 2088-0154 (Online) 7

12. Supriyanta. Knowledge Management Untuk Peningkatan Pelayanan Akademik Pada Perguruan Tinggi, Vol 2, No 1

13. Utomo, A. P., \& Mariana, N. (2011). Analisis Tata Kelola Teknologi Informasi (It Governance) Pada Bidang Akademik Dengan Cobit Frame Work Studi Kasus Pada Universitas Stikubank Semarang. Dinamik-Jurnal Teknologi Informasi 